\title{
The association between high-sensitivity C-reactive protein and blood pressure in Yi people
}

\author{
Li Pan ${ }^{1 \dagger}$, Guoju Li ${ }^{2 \dagger}$, Shaoping Wan ${ }^{3}$, WuLi Yihuo ${ }^{4}$, Fang Yang ${ }^{5}$, Zheng Li ${ }^{5}$ and Guangliang Shan ${ }^{1 *}$
}

\begin{abstract}
Background: High-sensitivity C-reactive protein (hs-CRP) is a common risk factor for developing cardiovascular disease. However, there has been no study reporting the relationship between hs-CRP and blood pressure in Yi adults. The aim of this study is to investigate the association between hs-CRP and blood pressure in Yi adults.

Methods: In this cross-sectional study, included subjects were 2916 Yi migrants or farmers aged 20-80 years, recruited by using a stratified cluster sampling method from Liangshan Yi Autonomous Prefecture of Sichuan Province in 2014. The directed acyclic graphs(DAG) was used to select a minimal sufficient adjustment sets of variables which would identification the unconfounded effect of hs-CRP and hypertension. Multiple linear and multinomial logit analysis were used to estimate the effect of hs-CRP on SBP/DBP/MAP/PP and the prevalence of prehypertension/hypertension after adjustment for the relevant confounders.
\end{abstract}

Results: The median level of hs-CRP was 1.20 (0.50-3.06) mg/L in Yi migrants, and 0.84(0.36-2.52) mg/L in Yi farmers, and the prevalence of high hs-CRP was $23.25 \%$. For hs-CRP $>3 \mathrm{mg} / \mathrm{L}$ group, the adjusted PP tended to have lower values ( $\beta=-1.49,95 \% \mathrm{Cl}:-2.49--0.49, P=0.0034)$ compared with $<1 \mathrm{mg} / \mathrm{L}$ group. After adjusting for confounders, there were no significant association between hs-CRP and prehypertension/hypertension $(P>0.05)$.

Conclusions: Our results suggest that high hs-CRP is prevalent in Yi people, and this study does not support hsCRP as a risk factor of prehypertension or hypertension.

Keywords: Blood pressure, High-sensitivity C-reactive protein (hs-CRP), Yi people

\section{Background}

As a primary risk factor of cardiovascular disease [1], hypertension has affected $23.2 \%$ of the Chinese adult population (approximately 244.5 million) with the age $\geq$ 18 years old [2]. Among various Blood Pressure (BP) indices, Systolic Blood Pressure (SBP), Diastolic Blood Pressure (DBP), Mean Arterial Pressure (MAP), and Pulse Pressure (PP) have been broadly applied [3]. It has been reported that even the slightly elevated blood pressure within the normal range may lead to cardiovascular morbidity and mortality $[4,5][6]$. As a pentagonal acute phase reactant molecule, high-sensitivity C-Reactive

\footnotetext{
* Correspondence: guangliang_shan@163.com

${ }^{\dagger} \mathrm{Li}$ Pan and Guoju Li contributed equally to this work.

'Department of Epidemiology and Statistics, Institute of Basic Medical Sciences, Chinese Academy of Medical Sciences, School of Basic Medicine, Peking Union Medical College, Beijing 100005, China

Full list of author information is available at the end of the article
}

Protein (hs-CRP) was initially produced in hepatocytes stimulated by interleukin-6 (IL-6) and Tumor Necrosis Factor (TNF), which were the biomarkers of systemic inflammation [7]. Hs-CRP was demonstrated to serve as an indicator to identify the risk of cardiovascular events in patients with high blood pressure [8-10]. Additionally, a meta-analysis of cohort studies revealed that high levels of hs-CRP was associated with the risk of hypertension development [11]. Although hs-CRP may be an early marker of hypertension, there is little evidence that confirmed the association between the levels of hs-CRP and BP indices. Besides, a variety of studies have indicated the inhomogeneity of the levels of hs-CRP among different ethnicities or races [12-14].

Ethnicity or race has been considered as the determining factor in the expression levels of biomarkers and played a crucial role in the relationship with cardiovascular

(c) The Author(s). 2019 Open Access This article is distributed under the terms of the Creative Commons Attribution 4.0 International License (http://creativecommons.org/licenses/by/4.0/), which permits unrestricted use, distribution, and 
diseases [15]. Located in the southwest of Sichuan Province, China, Liangshan Yi Autonomous Prefecture consists of 17 counties (cities) and $48.9 \%$ of Yi ethnic people, which is the largest Yi community in China [16]. Due to the isolation from the outside world, the farmers in Yi population have maintained the less acculturated lifestyle. In contrast to the farmers, the migrants in $\mathrm{Yi}$ population and Han residents who lived in the same communities with the similar diets composed of rice, meat and fresh vegetables, have experienced a evolution from the traditional lifestyle to the more typical urbanized one with higher fat intake [17]. Several researches have investigated hs-CRP in Yi people and the data revealed that there was no correlation between hs-CRP and BPs. Therefore, the objective of this study was to explore the relationship between hs-CRP and BPs in the adults of $\mathrm{Yi}$ population.

\section{Methods}

\section{Study population}

This Study was conducted from April 2015 to November 2015 in Liangshan Yi Autonomous Prefecture, Sichuan Province. The sampling procedure has been published in detail [18]. By using stratified cluster sampling method, the Yi people aged 20 to 80 years were selected as the subjects of the survey. The Liangshan Yi Autonomous Prefecture was stratified into urban and rural areas, and Xichang city was selected from urban areas and Puge County was selected from rural areas by using the convenience sampling. In each area, different communities or townships were treated as sampling units and three communities from Xichang City, five rural townships from Puge County were randomly selected. All Yi farmers in selected villages were surveyed. The Yi migrants were Yi people who had migrated to a county or Xichang city for over 1 year prior to the survey. The survey was approved by the Institutional Review Board of the Institute of Basic Medical Sciences, Chinese Academy of Medical Sciences, and informed consent was obtained from all participants.

\section{Health survey}

Demographic information, smoking habit, alcohol drinking habit and history of diseases were collected by unified questionnaires. Ethnicity was determined based on the subjects' ID card. Yi people were defined as the individuals and they and their parents were all Yi people. Subjects were classified as smokers (smoke more than one cigarette per day and last more than 6 months), former smoker and never smoker. For alcohol consumption, subjects were classified as current drinker (ever drinking), former drinker, and never drinker.

\section{Measurements}

Height and weight were measured with no shoes and light clothing by trained research assistants using a measurement device (BC-420, TANITA). Body Mass Index (BMI) was calculated as the weight in kilograms divided by the square of height in meters. Sitting blood pressure were collected triply by experienced physicians based on the HEM-907 equipment on the right arm positioned at heart level after a rest for $10 \mathrm{~min}$ and the subjects were not allowed to smoke, exercise or feed. Three independent measurements were averaged for all analyses.

After overnight fasting (at least $8 \mathrm{~h}$ ), blood samples were taken and processed immediately. And then they were refrigerated, transported to Beijing laboratory and stored below minus $80^{\circ} \mathrm{C}$ before analysis. Total cholesterol (TC), triglycerides (TG), high-density lipoprotein cholesterol (HDL-C), low-density lipoprotein cholesterol (LDL-C), and hs-CRP was measured by immunoturbidimetry. Hepingli Hospital laboratory passed the quality control test conducted by National Center for Clinical Laboratories, where daily dual-level indoor quality control was taken.

\section{Definitions}

Hs-CRP was classified according to the recommendation of the American Heart Association and Center for Disease Control, defining hs-CRP $<1 \mathrm{mg} / \mathrm{L}$ as low risk, between 1 and $3 \mathrm{mg} / \mathrm{L}$ as moderate risk, and $>3 \mathrm{mg} / \mathrm{L}$ as high risk [19].

BMI was divided into three groups, including thin or healthy $\left(\mathrm{BMI}<25 \mathrm{~kg} / \mathrm{m}^{2}\right)$, overweight $(25<\mathrm{BMI}<29 \mathrm{~kg} /$ $\left.\mathrm{m}^{2}\right)$ and obese $\left(B M I \geq 30 \mathrm{~kg} / \mathrm{m}^{2}\right)$ groups based on the criteria made by World Health Organization [20]. Dyslipidemia was defined as Total Cholesterol $(\mathrm{TC}) \geq 6.22$ $\mathrm{mmol} / \mathrm{L}$ and/or triglyceride (TG) $\geq 2.26 \mathrm{mmol} / \mathrm{L}$ and/or High Density Lipoprotein Cholesterol (HDL-C) $<1.04$ $\mathrm{mmol} / \mathrm{L}$ and/or Low Density Lipoprotein Cholesterol $(\mathrm{LDL}-\mathrm{C}) \geq 4.14 \mathrm{mmol} / \mathrm{L}$ [21]. Three clusters including optimal blood pressure, prehypertension, and hypertension, optimal blood pressure were grouped on account of blood pressure. Specifically, the average SBP $<120$ $\mathrm{mmHg}$ and $\mathrm{DBP}<80 \mathrm{mmHg}$ were considered as optimal blood pressure, and the average SBP ranging from 120 to $139 \mathrm{mmHg}$ and/or DBP $80-89 \mathrm{mmHg}$ as prehypertension [22]. Besides, hypertension was reported as the mean $\mathrm{SBP} \geq 140 \mathrm{mmHg}$, and/or $\mathrm{DBP} \geq 90 \mathrm{mmHg}$, or self-reported diagnosis of hypertension [23].

\section{Statistical analysis}

About $11 \%$ of the individuals were excluded from the analysis due to missing data on hs-CRP or other variable and excluding these adults would reduce statistical power and increased the likelihood of residual confounding. 
So we used multivariate imputation(MI) to fill out the missing values [24]. The directed acyclic graphs(DAG) was used to select a minimal sufficient adjustment sets of variables which would identification the unconfounded effect of hsCRP and blood pressure, and the DAG was implemented by DAGitty $[25,26]$. The DAG was implemented by identifying the main risk factors affecting hs-CRP or hypertension. We finally included gender, age, education, history of hypertension, smoking, overweight/ obesity and dyslipidemia (Fig. 1). The Yi farmers or Yi migrants were the main factor of this study, so we also included it. Excluding individuals receiving pharmacological treatment for hypertension may have resulted in selection bias if the decision to treat was influenced by other conditions associated with hs-CRP levels, and to address this issue, we included treatment as a factor in the analysis.

Continuous variables were described as mean $\pm \mathrm{SD}$, and categorical variables were expressed as numbers and percentages. For skewed variables (triglyceride levels, hsCRP), median (inter-quartile range) were used. MAP was defined as DBP plus 1/3 PP, and PP was defined as SBP minus DBP. Trend tests across different levels of hs-CRP for continuous and categorical variables were conducted using general linear model and CochranArmitage test, correspondingly. With the increase of hs$\mathrm{CRP}$, the increasing trends in mean systolic blood pressure (SBP), diastolic blood pressure (DBP), mean arterial pressure (MAP), and pulse pressure (PP) values were tested by the analysis of covariance.

Multiple linear and multinomial logit analysis were used to estimate the effect of hs-CRP on SBP/DBP/MAP/ $\mathrm{PP}$ and the prevalence of prehypertension/hypertension after adjustment for gender, age, Yi farmers or Yi migrants, education, history of hypertension, smoking, overweight/obesity and dyslipidemia.

We also evaluated the interaction between age and gender, age and overweight/obesity interaction terms in the regression models. The age-squared was included in the regression models to account for the non-linearity. This way to select model factors and functional forms avoided the bias. Hosmer and Lemeshow test was used to test the fit of the Logistic model, Studentized residual and Cook's distance were used to test the fit of the linear models.

\section{Results}

The analysis included 2916 individuals, of which 1204(41.29\%) were Yi migrants. The average age was $47.77 \pm 14.33$ years in Yi migrants, and $45.16 \pm 12.74$ years in Yi farmers. Compared with the Yi farmers, the Yi migrants had higher proportions of females, high education level, alcohol drinkers, family history of hypertension, and were more likely to have a higher BMI, TC, TG, LDL-C, SBP, DBP, MAP and hs-CRP (all $P<0.05$ ). Yi farmers appeared to have a higher HDL-C compared with Yi migrants $(P<0.05)$. The median of hs-CRP level was $1.20(0.50-3.06) \mathrm{mg} / \mathrm{L}$ in Yi migrants, and 0.84(0.36-2.52) $\mathrm{mg} / \mathrm{L}$ in Yi farmers(Table 1).

The characteristics of the subjects stratified by the levels of C-reactive protein for Yi farmers and $\mathrm{Yi} \mathrm{mi-}$ grants are shown in Table 2. Mean age, BMI, TC, TG, LDL cholesterol, SBP, DBP, MAP, the proportion of smokers, alcohol drinkers and dyslipidemia increased with hs-CRP (all $P$ for trend $<0.05$ ), while the mean level of HDL cholesterol decreased $(P$ for trend $<0.001)$ in both Yi farmers and Yi migrants. Mean PP increased with hs-CRP $(P$ for trend $<0.001)$ in Yi migrants.

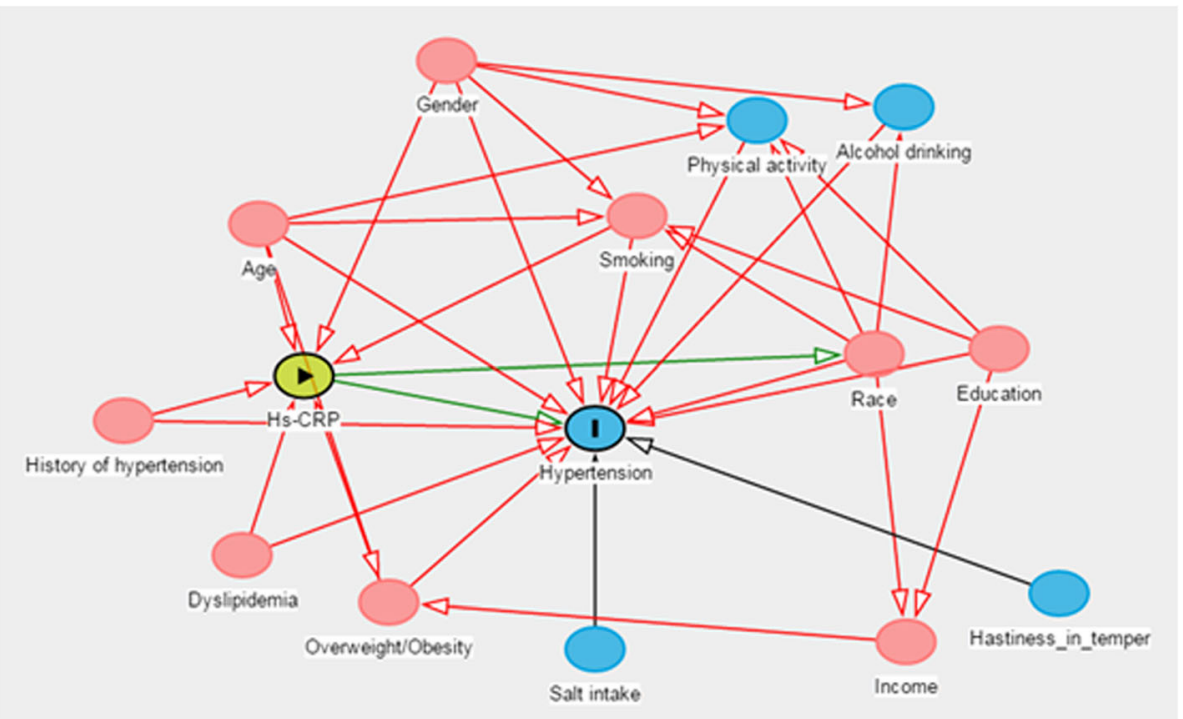

Fig. 1 Directed acyclic graph (DAG) for the confounded effect of hs-CRP and hypertension 
Table 1 Characteristics of the study population according to location

\begin{tabular}{|c|c|c|c|}
\hline Characteristics & Yi migrants $(N=1204)$ & Yi farmers $(N=1712)$ & $P$ value \\
\hline Male, \% & 373(30.98) & 577(33.70) & 0.12 \\
\hline Age, mean(SD), y & $47.77 \pm 14.33$ & $45.16 \pm 12.74$ & $<0.0001$ \\
\hline $\mathrm{BMl}$, mean(SD), kg/m² & $24.27 \pm 3.84$ & $22.11 \pm 3.55$ & $<0.0001$ \\
\hline Cigarette Smokers, \% & $365(30.32)$ & $562(32.83)$ & 0.15 \\
\hline Alcohol drinkers, \% & $513(42.71)$ & $647(37.84)$ & 0.0081 \\
\hline Family history of hypertension, \% & 120(9.97) & $57(3.33)$ & $<0.0001$ \\
\hline Education Level > elementary, \% & $586(48.67)$ & 194(11.33) & $<0.0001$ \\
\hline Total cholesterol, mmol/L & $5.08 \pm 1.01$ & $4.96 \pm 1.01$ & 0.0034 \\
\hline Triglycerides, mmol/L & $1.41(1.01-2.02)$ & $1.12(0.85-1.61)$ & $<0.0001$ \\
\hline LDL cholesterol, mmol/L & $3.17 \pm 0.90$ & $3.06 \pm 0.86$ & 0.0008 \\
\hline HDL cholesterol, mmol/L & $1.18 \pm 0.29$ & $1.24 \pm 0.30$ & $<0.0001$ \\
\hline Dyslipidemia,\% & $568(47.18)$ & $641(37.44)$ & $<0.0001$ \\
\hline Systolic blood pressure, mmHg & $121.40 \pm 18.84$ & $118.40 \pm 16.45$ & $<0.0001$ \\
\hline Diastolic blood pressure, mmHg & $74.92 \pm 11.14$ & $72.07 \pm 10.95$ & $<0.0001$ \\
\hline Pluse pressure, mmHg & $46.46 \pm 12.82$ & $46.30 \pm 10.82$ & 0.72 \\
\hline Mean arterial pressure, $\mathrm{mmHg}$ & $90.41 \pm 12.83$ & $87.50 \pm 12.00$ & $<0.0001$ \\
\hline C-Reactive Protein, mg/L & $1.20(0.50-3.06)$ & $0.84(0.36-2.52)$ & $<0.0001$ \\
\hline
\end{tabular}

Data are presented as means \pm SD or $n$ (\%) or median (Interquartile range)

The symbol "bold" reflected the $P<0.05$

Table 3 presents the results of association between hsCRP levels and BP. In the unadjusted analyses, compared with the hs-CRP $<1 \mathrm{mg} / \mathrm{L}$ group, the $1-3 \mathrm{mg} / \mathrm{L}$ and $>3 \mathrm{mg} / \mathrm{L}$ groups appeared to have a higher values of SBP, DBP, PP and MAP (all $P<0.05$ ). After adjusting for gender, age, age2, gender*age, Yi farmers or Yi migrants, education, family history of hypertension, smoking, overweight/obesity, age*overweight/obesity, pharmacological treatment for hypertension, and dyslipidemia, the PP $(\beta=-1.49,95 \% \mathrm{CI}:-2.49--0.49, P=0.0034)$ appeared to have lower values in hs-CRP $>3 \mathrm{mg} / \mathrm{L}$ group.

Table 4 presents the results of the associations between hs-CRP levels and prehypertension/hypertension. In crude models, higher prevalence of prehypertension/hypertension were associated with increasing levels of hs-CRP (all OR > $1, P<0.05)$. Then we only adjusted gender and age and found the prevalences of pre-hypertension and hypertension were both higher in hs-CRP 1-3 mg/L group (all OR > $1, P<0.05$ compare with hs-CRP $<1 \mathrm{mg} / \mathrm{L}$ group), and the prevalence of hypertension was higher in hs-CRP $>3 \mathrm{mg} / \mathrm{L}$ group $(\mathrm{OR}=1.69,95 \% \mathrm{CI}$ : 1.29-2.22). After multiple confounders adjustment described before, there were no significant association between hs-CRP and prehypertension/ hypertension $(P>0.05)$.

\section{Discussion}

To the best of our knowledge, this is the first study to investigate the association between hs-CRP and $\mathrm{BP}$ in $\mathrm{Yi}$ people in Liangshan Yi Autonomous Prefecture. In this study, the prevalence of high hs-CRP was $23 \%$, and one study reported the prevalence of high hs-CRP was approximately $25 \%$ in the general population in the United States [27]. Another study of 11623 middle-aged Chinese people reported the prevalence of hs-CRP $\geq 3 \mathrm{mg} / \mathrm{L}$ as $12.3 \%$, and the median hs-CRP level of the study was 0.80 $\mathrm{mg} / \mathrm{L}$, which was similar to ours at $0.99 \mathrm{mg} / \mathrm{L}$ [28]. A meta-analysis also reported the median level of hs-CRP was $0.97 \mathrm{mg} / \mathrm{L}$ in East Asian [12]. In general, several reports pointed out Asian people had lower hs-CRP levels than western people did. Women's Health Across the Nation (SWAN) study showed that African-American women had the highest median hs-CRP level $(3.2 \mathrm{mg} / \mathrm{L})$, followed by Hispanic $(2.3 \mathrm{mg} / \mathrm{L})$, white $(1.5 \mathrm{mg} / \mathrm{L})$, Chinese $(0.7 \mathrm{mg} / \mathrm{L})$, and Japanese $(0.5 \mathrm{mg} / \mathrm{L})$ women [29].

Another important finding was hs-CRP was positively associated with SBP, DBP, MAP and PP. However, the associations did not persist after the adjusting for relevant confounders. An interesting result was that PP showed to be lower in hs-CRP $>3 \mathrm{mg} / \mathrm{L}$ group. There were few studies conducted the associations between hs-CRP and blood pressure. A cross-sectional study conducted among workers from the Colombian Oil Company showed DBP was higher for subjects in the second and fourth quartile of CRP groups [8]. Surapon et al found that hs-CRP concentration was significantly correlated with SBP and DBP but they did not study the confounders adjustment associations [30]. A further study is urgently needed to clarify the association between the hs-CRP and BP. 
Table 2 Comparison of characteristics among 2716 Yi people according to level of C-reactive protein among Yi farmers and Yi migrants

\begin{tabular}{|c|c|c|c|c|}
\hline \multirow[t]{2}{*}{ Characteristics } & \multicolumn{3}{|c|}{ Level of C-Reactive Protein, mg/L } & \multirow{2}{*}{$\begin{array}{l}\text { P for } \\
\text { Trend }\end{array}$} \\
\hline & $<1$ & $1 \sim 3$ & $>3$ & \\
\hline \multicolumn{5}{|l|}{ Yi migrants } \\
\hline Number & 529 & 369 & 306 & \\
\hline C-Reactive Protein, median(interquartile range), mg/L & $0.43(0.26-0.67)$ & $1.64(1.27-2.19)$ & $5.92(4.32-11.09)$ & \\
\hline Age, mean(SD), y & $43.22 \pm 13.21$ & $50.08 \pm 14.10$ & $52.87 \pm 14.12$ & $<0.0001$ \\
\hline $\mathrm{BMI}$, mean(SD), kg/m² & $23.20 \pm 3.26$ & $24.97 \pm 3.73$ & $25.27 \pm 4.39$ & $<0.0001$ \\
\hline Cigarette Smokers, \% & 136(25.71) & $116(31.44)$ & 113(36.93) & 0.0006 \\
\hline Alcohol drinkers, \% & 204(38.56) & 169(45.92) & 140(46.05) & 0.021 \\
\hline Education Level > elementary, \% & 264(49.91) & 190(51.49) & $132(43.14)$ & 0.1 \\
\hline Family history of hypertension, \% & $54(10.21)$ & $36(9.76)$ & $30(9.80)$ & 0.83 \\
\hline Total cholesterol, mmol/L & $4.93 \pm 0.99$ & $5.15 \pm 0.99$ & $5.25 \pm 1.06$ & $<0.0001$ \\
\hline Triglycerides, mmol/L & $1.22(0.91-1.75)$ & $1.53(1.11-2.17)$ & $1.61(1.16-2.21)$ & $<0.0001$ \\
\hline LDL cholesterol, mmol/L & $3.04 \pm 0.88$ & $3.24 \pm 0.85$ & $3.31 \pm 0.95$ & $<0.0001$ \\
\hline HDL cholesterol, mmol/L & $1.24 \pm 0.30$ & $1.14 \pm 0.27$ & $1.10 \pm 0.27$ & $<0.0001$ \\
\hline Dyslipidemia,\% & 184(34.78) & 198(53.66) & 186(60.78) & $<0.0001$ \\
\hline Systolic blood pressure, mmHg & $117.47 \pm 17.76$ & $124.28 \pm 19.22$ & $124.66 \pm 18.99$ & $<0.0001$ \\
\hline Diastolic blood pressure, mmHg & $73.18 \pm 11.04$ & $76.21 \pm 11.06$ & $76.38 \pm 11.04$ & 0.0001 \\
\hline Pulse pressure, mmHg & $44.29 \pm 11.38$ & $48.07 \pm 14.02$ & $48.28 \pm 13.11$ & $<0.0001$ \\
\hline Mean arterial pressure, $\mathrm{mmHg}$ & $87.94 \pm 12.55$ & $92.23 \pm 12.69$ & $92.48 \pm 12.78$ & $<0.0001$ \\
\hline \multicolumn{5}{|l|}{ Yi farmers } \\
\hline Number & 936 & 404 & 372 & \\
\hline C-Reactive Protein, median(interquartile range), mg/L & $0.39(0.24-0.60)$ & $1.70(1.35-2.23)$ & $6.59(4.19-11.95)$ & \\
\hline Age, mean(SD), y & $43.31 \pm 12.20$ & $47.33 \pm 13.04$ & $47.47 \pm 13.03$ & $<0.0001$ \\
\hline BMl, mean(SD), kg/m² & $21.58 \pm 3.02$ & $22.82 \pm 3.76$ & $22.65 \pm 4.28$ & 0.0001 \\
\hline Cigarette Smokers, \% & $259(27.67)$ & 147(36.39) & 156(41.94) & $<0.0001$ \\
\hline Alcohol drinkers, \% & $306(32.73)$ & 166(41.19) & 175(47.04) & $<0.0001$ \\
\hline Education Level > elementary, \% & 93(9.94) & $54(13.37)$ & $47(12.63)$ & 0.09 \\
\hline Family history of hypertension, \% & $32(3.42)$ & $14(3.47)$ & $11(2.96)$ & 0.71 \\
\hline Total cholesterol, mmol/L & $4.89 \pm 0.94$ & $5.10 \pm 0.99$ & $5.00 \pm 1.18$ & 0.0211 \\
\hline Triglycerides, mmol/L & $1.07(0.82-1.50)$ & $1.21(0.89-1.77)$ & $1.17(0.91-1.74)$ & $<0.0001$ \\
\hline LDL cholesterol, mmol/L & $3.00 \pm 0.80$ & $3.16 \pm 0.86$ & $3.09 \pm 0.98$ & 0.0154 \\
\hline HDL cholesterol, mmol/L & $1.27 \pm 0.29$ & $1.23 \pm 0.31$ & $1.15 \pm 0.31$ & $<0.0001$ \\
\hline Dyslipidemia,\% & $279(29.81)$ & $172(42.57)$ & 190(51.08) & $<0.0001$ \\
\hline Systolic blood pressure, $\mathrm{mmHg}$ & $116.80 \pm 15.75$ & $120.48 \pm 17.23$ & $120.02 \pm 16.93$ & 0.0002 \\
\hline Diastolic blood pressure, $\mathrm{mmHg}$ & $70.94 \pm 10.49$ & $72.55 \pm 10.99$ & $74.37 \pm 11.65$ & $<0.0001$ \\
\hline Pulse pressure, mmHg & $45.86 \pm 10.32$ & $47.93 \pm 11.74$ & $45.65 \pm 10.85$ & 0.63 \\
\hline Mean arterial pressure, mmHg & $86.23 \pm 11.50$ & $88.52 \pm 12.20$ & $89.59 \pm 12.64$ & $<0.0001$ \\
\hline
\end{tabular}

Data are presented as means \pm SD or $n$ (\%) or median (Interquartile range)

The symbol "bold" reflected the $P<0.05$

In this cross-sectional research of Yi people, the high prevalence of pre-hypertension and hypertension were observed, which were associated with the elevated hsCRP. However, the correlation was unsustainable after adjusting for relevant confounders. It was demonstrated in a large number of studies that the levels of hs-CRP were up-regulated in the patients with pre-hypertension than that of the subjects with normal BPs [31, 32]. Nevertheless, hs-CRP could not be confirmed as the risk factor for hypertension by the above results. In fact, 


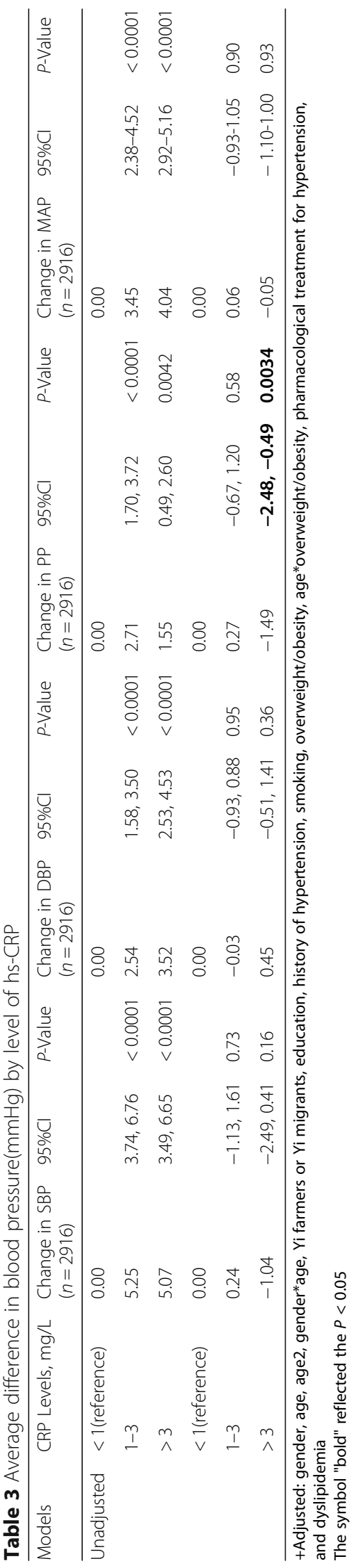


Table 4 Association between blood pressure levels and C-reactive protein by multivariate logistic regression models

\begin{tabular}{|c|c|c|c|c|c|c|}
\hline \multirow{2}{*}{$\begin{array}{l}\text { CRP } \\
\text { Levels }\end{array}$} & \multicolumn{3}{|c|}{ Pre-hypertension Odds Ratio (95\%Cl) $(n=865)$} & \multicolumn{3}{|c|}{ Hypertension Odds Ratio $(95 \% \mathrm{Cl})(n=491)$} \\
\hline & Unadjusted & Age and sex adjusted & Multivariate adjusted+ & Unadjusted & Age and sex adjusted & Multivariate adjusted+ \\
\hline$<1$ & 1 & 1 & 1 & 1 & 1 & 1 \\
\hline $1-3$ & $1.64(1.35-2.00) *$ & $1.37(1.12-1.69) *$ & $1.06(0.85-1.32)$ & $2.26(1.76-2.90) *$ & $1.57(1.20-2.05) *$ & $1.08(0.81-1.43)$ \\
\hline$>3$ & $1.57(1.27-1.94) *$ & $1.22(0.98-1.52)$ & $0.91(0.72-1.16)$ & $2.75(2.14-3.54) *$ & $1.69(1.29-2.22) *$ & $1.11(0.83-1.48)$ \\
\hline
\end{tabular}

${ }^{*}$ Compared with hs-CRP $<1: P<0.05 ;+$ Adjusted: gender, age, age2, gender*age, Yi farmers or Yi migrants, education, history of hypertension, smoking, overweight/obesity, age*overweight/obesity, and dyslipidemia

The symbol "bold" reflected the $P<0.05$

several epidemiological researches have indicated the unsustainability of the relationship between hs-CRP and BP. CARDIA has demonstrated that there was no significant association between hs-CRP and hypertension in perimenopausal (1.12 [0.99-1.27]) or postmenopausal (1.09 [0.95-1.26]) women [33]. The study published by Tanno-Sobetsu, as a prospective cohort study conducted in Japan, showed that there was no correlation between the high hs-CRP alone and the increased development of hypertension in both men and women [34]. However, most studies suggested that hs-CRP was positively associated with hypertension. A large cohort study followed for a median of 7.8 years revealed that the levels of hsCRP played critical roles in the further development of hypertension, suggesting hypertension was part of inflammatory disorders [9]. Furthermore, it was demonstrated in another research followed for a median of 11 years that incident hypertension could be predicted by several independent factors including hs-CRP, abdominal obesity and smoking behavior [35]. It was also suggested that there was a remarkable correlation between CRP and incident hypertension after the normalization of other biomarkers [36]. Besides, BP was up-regulated by high levels of hs-CRP through inhibiting the nitric oxide production in endothelial cells [37, 38], resulting in vasoconstriction and evaluated production of endothelin 1 [39]. A meta-analysis of cohort studies represented that hs-CRP served as a risk indicator of the formation of hypertension, which also proven that stronger associations were existed in USA than in Asia (RRs: 1.73 vs. 1.03) [11], indicating that the regional differences in the effects of hs-CRP on hypertension should be taken into consideration. The regional differences may be explained by different ethnicities or races, which also led to various levels of hs-CRP [12-14]. It was also illustrated in a research conducted in South Africa among Caucasian and African women that the levels of hs-CRP was higher in African women $(4.91 \mathrm{mg} / \mathrm{L}$ vs. $2.99 \mathrm{mg} / \mathrm{L})$, which suggested the ethnic differences [40]. Additionally, for Yi people, hs-CRP and its associations with BPs were not obvious which provided relevant information.

There are still some limitations in this study. First, this is a cross-sectional study, and the results could not represent causal relations. Second, hs-CRP in this study was only assessed from one blood sample. But a trial indicated that the median hs-CRP concentration is close to the mean based on a cohort over 4 years [41]. Furthermore, although this sample is representative of the general population, some people with inflammatory diseases may be still included in the high hs-CRP group and further cohort studies should conducted to avoided this bias.

\section{Conclusions}

In conclusion, this cross-sectional study shows that high hs-CRP is prevalent in Yi people, the effects of hs-CRP on SBP, DBP and MAP were relatively weak, however, compared with the hs-CRP $<1 \mathrm{mg} / \mathrm{L}$ group, the PP appeared to have lower values in hs-CRP $>3 \mathrm{mg} / \mathrm{L}$ group. This study does not support hs-CRP as a risk factor of prehypertension or hypertension. Further cohort studies should be conducted to clarify whether hs-CRP is a predictor of hypertension or not.

\section{Abbreviations}

BMI: Body mass index; DBP: Diastolic blood pressure; MAP: Mean arterial pressure; PP: Pulse pressure; SBP: Systolic blood pressure

\section{Acknowledgements}

We sincerely express our gratitude to all staff of Xichang Municipal Center for Disease Control and Prevention, Puge County Center for Disease Control and Prevention for their helping in performing field work, we also express our gratitude to Li pan, Fen Dong, Haiying Gong, Guodong Xu, Yanlong Li, Jia Zhang, Xiaoyang Wang, Biao Zhang for the data collection.

\section{Authors' contributions}

$L P$ and GJL participated in the data collection and drafted the manuscript. SPW, WLYH, FY and ZL, participated in the data collection. GLS participated in the design of the study and undertook statistical analyses. All authors approved the final manuscript.

\section{Funding}

This study was supported by grants from the National natural science foundation of China (Grant No.81273158). The funder had no role in the design of the study and collection, analysis, and interpretation of data and in writing the manuscript.

\section{Availability of data and materials}

The datasets used during the present study are available from the corresponding author upon reasonable request.

\section{Ethics approval and consent to participate}

The study was approved by the Institutional Review Board of the Institute of Basic Medical Sciences, Chinese Academy of Medical Sciences (033-2012), and all participants written informed consent. The study was performed in accordance with approved national guidelines. 


\section{Consent for publication}

Not applicable.

\section{Competing interests}

The authors declare that they have no competing interests.

\section{Author details}

${ }^{1}$ Department of Epidemiology and Statistics, Institute of Basic Medical Sciences, Chinese Academy of Medical Sciences, School of Basic Medicine, Peking Union Medical College, Beijing 100005, China. ${ }^{2}$ Qingdao Women and Children's Hospital, Qingdao University, Qingdao 266011, Shandong, China. ${ }^{3}$ Sichuan Provincial Hospital, Chengdu, China. ${ }^{4}$ Department for Chronic Noncommunicable Diseases Control, Puge County Center for Disease Control and Prevention, Xichang, Sichuan, China. ${ }^{5}$ Xichang Municipal Center for Disease Control and Prevention, Xichang, Sichuan, China.

\section{Received: 13 November 2018 Accepted: 16 July 2019}

\section{Published online: 24 July 2019}

\section{References}

1. Rapsomaniki E, Timmis A, George J, Pujades-Rodriguez M, Shah AD, Denaxas S, White IR, Caulfield MJ, Deanfield JE, Smeeth L, et al. Blood pressure and incidence of twelve cardiovascular diseases: lifetime risks, healthy life-years lost, and age-specific associations in 1.25 million people. Lancet. 2014; 383(9932):1899-911.

2. Wang Z, Chen Z, Zhang L, Wang X, Hao G, Zhang Z, Shao L, Tian Y, Dong Y, Zheng $C$, et al. Status of hypertension in China: results from the China hypertension survey, 2012-2015. Circulation. 2018;137(22):2344-56.

3. Pickering TG, Hall JE, Appel LJ, Falkner BE, Graves J, Hill MN, Jones DW, Kurtz T, Sheps SG, Roccella EJ. Recommendations for blood pressure measurement in humans and experimental animals: part 1: blood pressure measurement in humans: a statement for professionals from the Subcommittee of Professional and Public Education of the American Heart Association Council on high blood pressure research. Circulation. 2005; 111(5):697-716.

4. vLewington S, Clarke R, Qizilbash N, Peto R, Collins R. Age-specific relevance of usual blood pressure to vascular mortality: a meta-analysis of individual data for one million adults in 61 prospective studies. Lancet. 2002;360(9349):1903-13.

5. Odden MC, McClure LA, Sawaya BP, White CL, Peralta CA, Field TS, Hart RG, Benavente OR, Pergola PE. Achieved Blood Pressure and Outcomes in the Secondary Prevention of Small Subcortical Strokes Trial. Hypertension. 2016:67(1):63-9.

6. Fuchs FD, Fuchs SC, Moreira LB, Gus M. Proof of concept in cardiovascular risk: the paradoxical findings in blood pressure and lipid abnormalities. Vasc Health Risk Manag. 2012:8:437-42.

7. Gilstrap LG, Wang TJ. Biomarkers and cardiovascular risk assessment for primary prevention: an update. Clin Chem. 2012;58(1):72-82.

8. Bautista LE, Lopez-Jaramillo P, Vera LM, Casas JP, Otero AP, Guaracao Al. Is C-reactive protein an independent risk factor for essential hypertension? J Hypertens. 2001;19(5):857-61.

9. Sesso HD, Buring JE, Rifai N, Blake GJ, Gaziano JM, Ridker PM. C-reactive protein and the risk of developing hypertension. Jama. 2003;290(22):2945-51.

10. Engelsen CD, Koekkoek PS, Gorter KJ, Donk MVD, Salomé PL, Rutten GE. High-sensitivity C-reactive protein to detect metabolic syndrome in a centrally obese population: a cross-sectional analysis. Cardiovasc Diabetol. 2012;11(1):25.

11. Jayedi A, Rahimi K, Bautista LE, Nazarzadeh M, Zargar MS, Shab-Bidar S. Inflammation markers and risk of developing hypertension: a meta-analysis of cohort studies. Heart. 2019:105(9):686-92

12. Shah $T$, Newcombe P, Smeeth $L$, Addo J, Casas JP, Whittaker J, Miller MA, Tinworth L, Jeffery S, Strazzullo P, et al. Ancestry as a determinant of mean population C-reactive protein values: implications for cardiovascular risk prediction. Circ Cardiovasc Genet. 2010;3(5):436-44.

13. Deeg M, Baiyewu O, Gao S, Ogunniyi A, Shen J, Gureje O, Taylor S, Murrell J, Unverzagt F, Smith-Gamble V, et al. A comparison of cardiovascular disease risk factor biomarkers in African Americans and Yoruba Nigerians. Ethn Dis. 2008;18(4):427-33.

14. Veeranna V, Zalawadiya SK, Niraj A, Kumar A, Ference B, Afonso L Association of novel biomarkers with future cardiovascular events is influenced by ethnicity: results from a multi-ethnic cohort. Int J Cardiol. 2013:166(2):487-93.

15. Abufarha M, Behbehani K, Elkum N. Comprehensive analysis of circulating adipokines and hsCRP association with cardiovascular disease risk factors and metabolic syndrome in Arabs. Cardiovasc Diabetol. 2014;13(1):1-10.

16. Shan G, Wei D, Wang C, Zhang J, Wang B, Ma M, Pan L, Yu T, Xue F, Wu Z. Trends of overweight and obesity in Yi people between 1996 and 2007: an Yi migrant study. Biomed Environ Sci. 2011;24(5):467-74.

17. Wang C, Wei D, Wang B, Zhang J, Zhang K, Ma M, Pan L, Yu T, Xue F, Shan $G$. Effect of lifestyle on the prevalence of the metabolic syndrome among farmers, migrants with $\mathrm{Yi}_{i}$ ethnicity and Han population in Sichuan province of China. Asia Pac J Clin Nutr. 2010;19(2):266-73.

18. Zhang J, Wan S, Zhang B, Dong F, Pan L, Yihuo W, Gong H, Yang F, Xu G, Li $Z$, et al. Twenty-year time trends in hypertension prevalence in $Y i$ people of China: three successive cross-sectional studies, 1996-2015. BMJ Open. 2018; 8(10):e022714.

19. Pearson TA, Mensah GA, Alexander RW, Anderson JL, Cannon RO 3rd, Criqui M, Fadl YY, Fortmann SP, Hong Y, Myers GL, et al. Markers of inflammation and cardiovascular disease: application to clinical and public health practice: a statement for healthcare professionals from the Centers for Disease Control and Prevention and the American Heart Association. Circulation. 2003;107(3):499-511.

20. Organization. WH: Global database on body mass index. Geneva: World Health Organization; 2008.

21. Flink L, Underberg JA, Newman JD, Gianos E. The recent national lipid association recommendations: how do they compare to other established dyslipidemia guidelines? Curr Atheroscler Rep. 2015;17(4):494

22. Chobanian AV, Bakris GL, Black HR, Cushman WC, Green LA, Izzo JL Jr, Jones DW, Materson BJ, Oparil S, Wright JT Jr, et al. The seventh report of the joint National Committee on prevention, detection, evaluation, and treatment of high blood pressure: the JNC 7 report. Jama. 2003;289(19):2560-72.

23. Egan BM, Zhao Y, Axon RN. US trends in prevalence, awareness, treatment, and control of hypertension, 1988-2008. Jama. 2010;303(20):2043-50.

24. van Buuren S, Boshuizen HC, Knook DL. Multiple imputation of missing blood pressure covariates in survival analysis. Stat Med. 1999;18(6):681-94.

25. Shrier I, Platt RW. Reducing bias through directed acyclic graphs. BMC Med Res Methodol. 2008:8:70.

26. Textor J. Drawing and Analyzing Causal DAGs with DAGitty. Nucleic Acids Res. 2015;32(10):3220-7.

27. Ridker PM. A test in context: high-sensitivity C-reactive protein. J Am Coll Cardiol. 2016;67(6):712-23.

28. Wang Z, Xin W, Zuo C, Zhang L, Zhu M. Distribution of high-sensitivity C-reactive protein and its relationship with other cardiovascular risk factors in the middleaged Chinese population. Int J Environ Res Public Health. 2016;13(9):872.

29. Kelley-Hedgepeth A, Lloyd-Jones DM, Colvin A, Matthews KA, Johnston J, Sowers MR, Sternfeld B, Pasternak RC, Chae CU, Investigators S. Ethnic differences in C-reactive protein concentrations. Clin Chem. 2008:54(6):1027-37.

30. Tangvarasittichai $S$, Pingmuanglaew $P$, Tangvarasittichai $O$. Association of Elevated Serum Lipoprotein(a), inflammation, oxidative stress and chronic kidney disease with hypertension in non-diabetes hypertensive patients. Indian J Clin Biochem. 2016;31(4):446-51.

31. Sathiyapriya V, Selvaraj N, Nandeesha H, Bobby Z, Aparna A, Pavithran P. Association between protein bound sialic acid and high sensitivity Creactive protein in prehypertension: a possible indication of underlying cardiovascular risk. Clin Exp Hypertens. 2008;30(5):367-74.

32. Gupta AK, Johnson WD. Prediabetes and prehypertension in disease free obese adults correlate with an exacerbated systemic proinflammatory milieu. J Inflamm. 2010;7:36.

33. Ebong IA, Schreiner P, Lewis CE, Appiah D, Ghelani A, Wellons M. The association between high-sensitivity C-reactive protein and hypertension in women of the CARDIA study. Menopause. 2016;23(6):662-8.

34. Fujii M, Ohnishi H, Saitoh S, Akasaka H, Miura T, Mori M. The combination of abdominal obesity and high-sensitivity C-reactive protein predicts newonset hypertension in the general Japanese population: the Tanno-Sobetsu study. Hypertens Res. 2015;38(6):426-32.

35. Niskanen L, Laaksonen DE, Nyyssonen K, Punnonen K, Valkonen VP, Fuentes $R$, Tuomainen TP, Salonen R, Salonen JT. Inflammation, abdominal obesity, and smoking as predictors of hypertension. Hypertension. 2004:44(6):859-65.

36. Wang TJ, Gona P, Larson MG, Levy D, Benjamin EJ, Tofler GH, Jacques PF, Meigs JB, Rifai N, Selhub J, et al. Multiple biomarkers and the risk of incident hypertension. Hypertension. 2007;49(3):432-8. 
37. Verma S, Wang CH, Li SH, Dumont AS, Fedak PW, Badiwala MV, Dhillon B, Weisel RD, Li RK, Mickle DA, et al. A self-fulfilling prophecy: C-reactive protein attenuates nitric oxide production and inhibits angiogenesis. Circulation. 2002:106(8):913-9.

38. Venugopal SK, Devaraj S, Yuhanna I, Shaul P, Jialal I. Demonstration that Creactive protein decreases eNOS expression and bioactivity in human aortic endothelial cells. Circulation. 2002;106(12):1439-41.

39. Devaraj S, Xu DY, Jialal I. C-reactive protein increases plasminogen activator inhibitor-1 expression and activity in human aortic endothelial cells: implications for the metabolic syndrome and atherothrombosis. Circulation. 2003;107(3):398-404

40. Schutte AE, van Vuuren D, van Rooyen JM, Huisman HW, Schutte R, Malan L, Malan NT. Inflammation, obesity and cardiovascular function in African and Caucasian women from South Africa: the POWIRS study. J Hum Hypertens. 2006:20(11):850-9.

41. Glynn RJ, Macfadyen JG, Ridker PM. Tracking of high-sensitivity C-reactive protein after an initially elevated concentration: the JUPITER study. Clin Chem. 2009;55(2):305-12.

\section{Publisher's Note}

Springer Nature remains neutral with regard to jurisdictional claims in published maps and institutional affiliations.

- fast, convenient online submission

- thorough peer review by experienced researchers in your field

- rapid publication on acceptance

- support for research data, including large and complex data types

- gold Open Access which fosters wider collaboration and increased citations

- maximum visibility for your research: over $100 \mathrm{M}$ website views per year

At $\mathrm{BMC}$, research is always in progress. 